\title{
PERSEPSI MUZAKKI TERHADAP PENGELUARAN ZAKAT DAN HUBUNGANNYA DENGAN PENINGKATAN KESEJAHTERAAN MUSTAHIQ DI KOTA PALOPO PROVINSI SULAWESI SELATAN
}

\author{
Muhammad Yus uf $\mathbf{Q}^{1}$, Hapid ${ }^{2}$ \\ Sekolah Tinggi Ilmu Ekonomi Muhammadiyah Palopo \\ E_Mail: Muhammad_yusuf@stiem.ac.id
}

\begin{abstract}
Abstrak: Tujuan jangka panjang penelitian adalah untuk menjadi masukan kepada pemerintah dalam bentuk kebijakan institusi Badan Amil Zakat (BAZ) terkait persepsi muzakki (wajib zakat) terhadap kesadaran pengeluaran zakat dan hubungannya dengan peningkatan kesejahteraan mustahiq di Kota Palopo Provinsi Sulawesi Selatan, sehingga dapat memberi manfaat yang berarti terhadap sistem dan kebijakan terhadap pengelolaan zakat bagi pemerintah dan masyarakat.

Target khusus yang akan dicapai dalam penelitian ini ; 1) Bagaimana menggali potensi zakat yang ada dalam masyarakat, 2) Penguatan lembaga pengelola zakat, seperti BAZNAS (dikelola pemerintah) dan LAZ (dikelola masyarakat), 3) Mekanisme pemberian/penyaluran zakat kepada mustahiq (yang berhak menerima zakat) yang lebih produktif, sehingga dapat berdampak secara nyata terhadap kesejahteraan mustahiq.

Metode yang akan digunakan dalampencapaian tujuan tersebut adalah metode penelitian kuantitatifyang titik beratnya diletakkan pada kenyataan sebenarnya, yakni mempelajari hubungan variabel-variabel yang menggunakan alat analisis statistik Partial Least Square (PLS). Permasalahan yang bersifat normatifdilakukan analisis kualitatif dengan metode intuitif (kasyf) untuk menelaah hakekat yang terkandung dalam pelaksanaan perintah zakat dan persepsi muzakki terhadap zakat.

Berdasarkan hasil perhitungan inner model dapat disimpulkan sebagai berikut: Dari hasil uji nilai tstatistics sebesar 20,8751, yang menunjukkan angka yang lebih besardarit-tabel $=1,96 . t$-statistik $(20,8751)>t$-tabel (1,96).Artinya Ho ditolak dan Ha diterima. Jadi dapat disimpulkan bahwa terdapat pengaruh yang signifikan dari variabel Pengeluaran ZIS terhadap Kesejahteraan Mustahiq, artinya bahwa semakin besar/baik pengeluaran ZIS, maka akan semakin besar / baik pula Kesejahteraan Mustahiq.
\end{abstract}

Kata kunci: Persepsi, Zakat, Muzakki, Mustahiq, BAZNAS

\begin{abstract}
PENDAHULUAN
Prinsip-prinsip dasar Islam tentang pembangunan dengan segala aspeknya, terutama masalah pembangunan ekonomi adalah suatu hal yang menarik untuk dikaji lebih mendalam, sebab disatu pihak diharapkan dapat memecahkan masalah-masalah ekonomi yang melanda dunia sepanjang masa dengan ajaran-ajarannya yang lengkap, sementara dilain pihak merupakan cabang dari ilmu pengetahuan yang dijiwai oleh ajaran agama Islam yang belum sepenuhnya dapat diterima oleh dunia secara keseluruhan.
\end{abstract}

Konsepsi Islam tentang perekonomian yang biasa juga disebut "Sistem Ekonomi
Islam/Syariah" lebih banyak menekankan aturanaturan perekonomian secara individu, sehingga unsur moral lebih dititik beratkan. Aturan-aturan pokok tentang perekonomian dalam Islam pada dasarnya sudah lengkap dan utuh, maka dalam upaya membangun perekonomian, selain formulasi-formulasi pemikiran baru yang berpangkal dari al-Qur'an dan Sunnah, juga dituntut adanya pembenahan moral bagi setiap individu pendukungnya.

Konsep ekonomi konvensional dewasa ini telah terbukti semakin mengukuhkan terakumulasinya faktor-faktor produksi pada sekelompok masyarakat (konglemerasi), sehingga semakin memperlebar gap antara orang-orang 
kaya dengan orang-orang miskin. Karena itu dibutuhkan pemikiran secara mendalam (kontemplatif) untuk memformulasi sistem ekonomi kedepan agar dapat membawa ummat manusia kepada kesejahteraan lahir dan bathin.

Konsep zakat dalam ekonomi Islam, adalah institusi yang menarik untuk dikaji lebih lanjut dalam kaitannya dengan persepsi muzakki terhadap kesadaran pengeluaran zakat, yang diharapkan dapat meningkatkan kesejahteraan mustahiq. Lebih jauh diharapkan akan memberikan gambaran secara jelas dan menyakinkan bahwa dengan ketaatan muzakki dalam membayar zakat, akan berdampak semakin membaiknya kualitas hidup dalam arti sejahtera lahir dan bathin, baik terhadap muzakki itu sendiri maupun terhadap mustahiq.

Dalam al-Qur'an telah digambarkan secara jelas sasaran dari zakat, sebagaimana Firman Allah
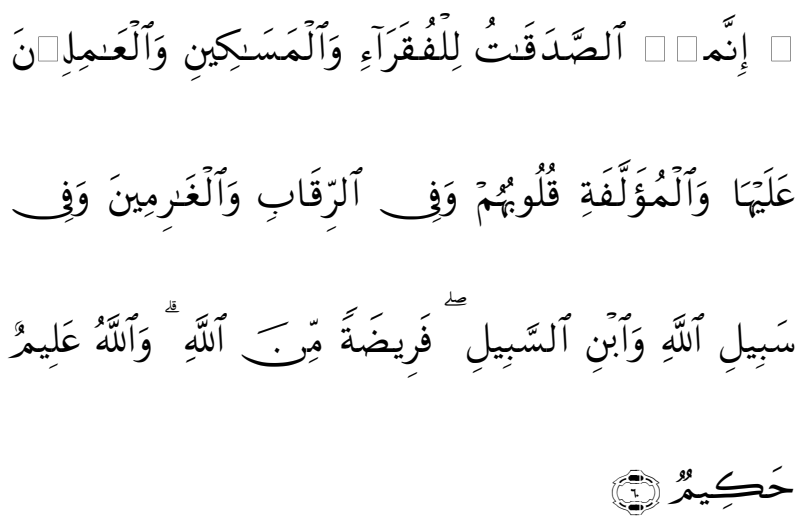

Artinya : Sesungguhnya zakat-zakat itu, hanyalah untuk orang-orang fakir, orang-orang miskin, penguruspengurus zakat, para mu'allaf yang dibujuk hatinya, untuk (memerdekakan) budak, orang-orang yang berhutang, untuk jalan Allah dan untuk mereka yang sedang dalam perjalanan, sebagai suatu ketetapan yang diwajibkan Allah, dan Allah Maha mengetahui lagi Maha Bijaksana. (Q.S. At-Taubah [9] : 60).

Zakat sesungguhnya dapat dijadikan sebagai sarana pengentasan kemiskinan karena dapat memperkecil kesenjangan pendapatan antar golongan dalam masyarakat, sekaligus dapat menjadi pintu bagi terciptanya motivasi pada sektor rill, jika pengelolaan zakat diarahkan pada bentuk yang lebih produktif.

Dewasa ini kondisi yang ada pada BAZNAS baik pada tingkat nasional, provinsi atau kabupaten/kota belum dikelola secara profesional dan belum menunjukkan keterbukaan manajemen pengelolaan ZIS yang baik. Hal ini terjadi karena memang secara internal masih terdapat permasalahan manajemen dan operasional pada lembaga-lembaga pengelola zakat. Disisi lain dapat juga kerena lembaga-lembaga pengelola zakat tersebut tidak (belum) membuka akses informasi yang luas bagi masyarakat untuk memperkenalkan dan menarik sebanyak mungkin sumber-sumber zakat dari masyarakat (muzakki). Karena itu dapat dipahami bahwa tingkat kepercayaan muzakki pada BAZNAS belum optimal.

\section{KAJIAN LITERATUR DAN PENGEMBANGAN HIPOTESIS}

\section{Pengertian Zakat}

Chapra $(2001 ; 333)$ mengemukakan bahwa zakat merupakan kewajiban relijius bagi seorang muslim, sama halnya dengan shalat, puasa dan naik haji, yang harus dikeluarkan sebagai proporsi tertentu terhadap kekayaan atau output bersihnya. 
Hasil zakat ini tidak dapat dibelanjakan oleh pemerintah sekehendak hatinya sendiri. Zakat ini merupakan instrumen relijius yang membantu individu dalam masyarakat untuk menolong penduduk yang miskin dan melarat yang tidak mampu menolong dirinya sendiri, agar kesengsaraan dan kemiskinan hilang dari masyarakat muslim.

Sedangkan makna zakat menurut kaidah bahasa (etimologis), Al-Utsaimin (2008; 45), mengemukakan bahwa zakat artinya bertambah dan berkembang. Setiap sesuatu yang bertambah jumlahnya atau berkembang ukurannya dinamakan zakat. Adapun menurut syara' yaitu ibadah kepada Allah SWT., dengan mengeluarkan bagian wajib secara syara' dari harta tertentu dan diberikan kepada sekelompok atau instansi (zakat) tertentu. Sedangkan hubungan kedua makna tersebut (makna secara bahasa dan syara') yaitu bahwasanya zakat itu meskipun secara lahirnya mengurangi kuantitas harta, namun dari sisi pengaruh (atsar) justru bertambah keberkahan dan jumlahnya. Karena apabila manusia menunaikan apa yang telah diwajibkan Allah kepadanya dalam masalah hartanya, boleh jadi Allah akan membukakan pintu-pintu rezekinya yang tidak pernah terlintas dalam pikirannya (Q.S. Saba' [34] : 39).

Dari sisi manfaat zakat, maka secara langsung ia diperuntukkan bagi manusia yang sedang berada dalam kekurangan. Akan tetapi secara tidak langsung zakat itu mempunyai kebaikan terhadap si pembayar zakat itu sendiri yang disebut dengan istilah muzakki, (Ali, 1988 : 30). Sebagaimana dijelaskan Allah SWT, dalam Q.S. Al-Baqarah [2] : 261
Selanjutnya untuk lebih memperjelas pemahaman antara Zakat, Infaq dan Shadaqah, Permono $(2005$, 56) mengutip pendapat Yusuf Qardawi, menjelaskan bahwa zakat menurut lughat, berarti barakah, tumbuh berkembang, suci bersih, baik dan terpuji, selanjutnya memberi penjelasan bahwa zakat dalam bahasa al-Qur'an dan as-Sunnah disebut juga dengan shadaqah.

Dari pengertian terakhir yang dikemukakan diatas, maka dapat dipahami bahwa dalam analisis selanjutnya pengertain Zakat, Infaq dan Shadaqah dipahami sebagai sesuatu yang sama. Namun demikian perlu dikemukakan pengertianpengertian tentang Infaq dan Shadqah dari berbagai pendapat.

\section{Konsep Kese jahteraan Konvensional}

Menurut Todaro (1987), kesejahteraan merupakan suatu hal yang bersifat subyektif. Karena setiap orang mempunyai pandangan hidup, tujuan hidup, dan cara hidup berbeda-beda, maka nilai yang diberikan kepada faktor-faktor yang menentukan tingkat kesejahteraan mereka pun berbeda-beda.

Suharjo (1998) menjelaskan pengertian kesejahteraan sebagai kemakmuran dan kebahagian. Kemakmuran berdimensi fisik yaitu terpenuhinya kebutuhan lahir atau fisik seperti pangan, sandang, kesehatan gizi, dan pendapatan. Sedangkan kebahagiaan disebut sebagai rasa aman dan tenterampada diri seseorang. Hal ini sejalan dengan pemikiran Sumardjan (1993), yang pernah mendeskripsikan kesejahteraan dalam dua konsep berbeda namun berkaitan, yaitu sejahtera dan bahagia. Sejahtera dilihat dari sudut ekonomi atau finansial sedangkan bahagia dilihat dari sudut psikologi. 
Biro Pusat Statistik (BPS) berupaya mengukur kesejahteraan rakyat dengan indikator dampak selain indikator input, proses dan output. Aspek-aspek yang diperhatikan oleh BPS mencakup enam variabel seperti : pendidikan, kesehatan, gizi, konsumsi dan pengeluaran rumah tangga, ketenaga kerjaan, serta perumahan dan lingkungan. Dari keenam variabel tersebut BPS menjabarkan aspek-aspek tersebut kedalam beberapa indikator :

Pendidikan ; angka melek huruf, tingkat pendidikan yang ditamat-kan, ketersediaan sarana pendidikan, dan partisipasi penduduk usia sekolah. Kesehatan ; sarana kesehatan, tenaga kesehatan, angka kematian bayi dan penyebab kematian, angka harapan hidup, angka kesakitan, penyakit menular, dan cara pengobatan.

Gizi ; penyediaan zat gizi dan asal bahan makanan, konsumsi energi dan protein, status gizi balita.

Konsumsi dan pengeluaran rumah tangga; pengeluaran rata-rata perkapita, pengeluaran untuk makanan, pengeluaran untuk bukan makanan, distribusi pengeluaran.

Ketenagakerjaan ; angka beban tanggungan angkatan kerja, status pekerjaan dan lapangan pekerjaan, jam kerja dan upah buruh, profil tingkat pendidikan angkatan kerja.

Perumahan dan lingkungan; fasilitas perumahan dan lingkungan jenis penerangan, air minum, bahan bakar, dan keadaan tempat tinggal.

\section{Konsep Kesejahteraan Menurut Islam}

Ghani (2005 ; 51-52), menjelaskan bahwa tingkat kesejahteraan dinyatakan dari jarak antara kebutuhan (need) dengan kenyataan (reality). Untuk mengelaborasi tentang makna sejahtera dalam kehidupan, ada beberapa pengertian yang harus dipahami secara seksama, yaitu : pandangan hidup (vision), cita-cita (idea), harapan (hope), keinginan (want), kebutuhan (need). Pandangan hidup merupakan koridor yang menuntun seseorang dalam prinsip hidupnya dan cara berpikirnya (mindset). Cita-cita, yaitu kehendak mencapai sesuatu keadaan yang untuk mencapainya membutuhkan proses panjang dengan syarat-syarat tertentu. Harapan, yaitu kehendak untuk mencapai keadaan, status, posisi tertentu, lebih baik dari yang dipegangnya saat ini. Keinginan, yaitu kehendak yang didasarkan cetusan hati dan sifatnya tidak terbatas. Kebutuhan, yaitu kehendak untuk memenuhi keperluan yang ada batasnya, makan tiga kali sehari merupakan kebutuhan, namun makan dengan menu kambing guling merupakan keinginan.

Gamal (2006 ; 15), menjelaskan bahwa kesejahteraan dalam pembangunan sosial ekonomi, tidak dapat didefinisikan hanya berdasarkan konsep materialis dan hedonis, tetapi juga memasukkan tujuan-tujuan kemanusiaan dan keruhanian. Tujuan-tujuan tersebut tidak hanya mencakup masalah kesejahteraan ekonomi, melainkan juga mencakup permasalahan persaudaraan manusia dan keadilan sosialekonomi, kesucian kehidupan, kehormatan individu, kehormatan harta, kedamaian jiwa dan kebahagiaan serta keharmonisan kehidupan keluarga dan masyarakat.

\section{Pengertian Muzakki}

Muzakki menurut Permono (2005 ; 251), adalah salah satu dari kategori masyarakat yaitu mereka memiliki pendapatan yang mampu untuk memenuhi kebutuhan pokoknya dan sisanya 
mencukupi satu nisab ; dan mereka wajib membayar zakat yang disebut dengan orang kaya. Rasulullah SAW bersabda "...zakat itu diambil dari orang-orang kaya diantara mereka dan dikembalikan kepada orang-orang fakir diantara mereka".

Pembayar zakat (muzakki) yaitu orang yang hartanya dikenakan kewajiban zakat. Seorang pembayar zakat disyaratkan harus muslim dan tidak disyaratkan baligh atau berakal menurut pendapat jumhur ulama fiqh. (Q.S.At-Taubah [9] ; 103).

\section{Pengertian Mustahiq}

Mengacu pada firman Allah SWT dalam surat At-Taubah ayat 60, bahwa terdapat 8 (delapan) ashnaf orang yang berhak menerima zakat atau yang disebut oleh Qardhawi (2005) sebagai sasaran zakat (masarif). Dari 8 ashnaf tersebut, Ali (1998 ; 48) membagi lagi menjadi tiga berdasarkan hak yaitu 1) hak fakir miskin, 2) hak masyarakat dan 3) hak Allah. Kemudian Mannan (1997 ; 267) mengatakan dari 8 ashnaf penerima zakat, enam diantaranya berkaitan dengan penduduk yang tergolong miskin (kemiskinan). Sedangkan Apraiyah (2007 ; 97), membagi menjadi tiga kategori yaitu pertama; berkaitan dengan orang-orang yang memerlukan pertolongan, meliputi orang-orang fakir, miskin, muallaf, budak, orang yang berutang dan musafir, kedua; orang-orang yang ditunjuk untuk mengumpulkan dan menyalurkan zakat serta ketiga; bagian dari zakat yang dibelanjakan dijalan Allah.

Mustahiq non-ashnaf adalah mustahiq yang menerima zakat, infaq dan shadaqah diluar ketentuan Al-Qur'an baik perorangan, kelompok maupun lembaga-lembaga sosial. Contoh yang diberikan Qardhawi (2005 ; 8) bahwa zakat merupakan suatu penggerak yang berpotensi memberikan tunjangan kepada para pedagang atau profesi lain yang membutuhkan modal, yang tidak bisa didapatkan dari jalan lain termasuk penganggur.

\section{METODE DAN BAHAN}

Penelitian ini akan dilaksanakan di Kota Palopo Provinsi Sulawesi Selatan, dengan pertimbangan bahwa masyarakat Kota Palopo memiliki potensi zakat yang besar. Dalam penelitiasn ini pengumpulan data yang dilakukan adalah :

1. Kuesioner, merupakan pengumpulan data secara langsung yang dilakukan dengan mengajukan daftar pertanyaan/peryataan pada muzakki yang menjadi sampel / responden dalam penelitian ini.

2. Wawancara, metode pengumpulan data dengan cara mengadakan wawancara pada muzakki dengan berpedoman pada pertayaan/pernyataan kepada responden dengan panduan kuesioner yang dibuat.

3. Dokumentasi, metode digunakan untuk memperoleh data sekunder, yaitu data yang akan diambil dari lembaga yang terkait dengan pengumpulan zakat, seperti BAZNAS dan LAZ yang ada di Kota Palopo Provinsi Sulawesi Selatan, dimana para muzakki yang menjadi sampel / responden bertempat tinggal.

Analisis data yang berbentuk kuantitatif dan hipotesis menggunakan analisis statistik Partial Least Square (PLS). Model kausal dalam PLS menunjukkan pengukuran dan masalah hubungan 
antar variabel secara struktural, dan digunakan untuk analisis dan menguji hipotesis studi yang sudah dideskripsikan sebelumnya. PLS sangat tepat untuk menganalisis kondisi seperti diatas karena kemampuannya untuk (Solimun, et. Al, 2006) :

a. Memperkirakan koefisien yang tidak diketahui dari persamaan linier struktural.

b. Mengakomodasi model yang meliputi laten variabel.

c. Mengakomodasi kesalahan pengukuran pada variabel dependen dan independen.

d. Mengakomodasi hubungan dan pengaruh yang timbal balik, simultan dan saling keterkaitan.

\section{HASIL DAN PEMBAHASAN}

\section{Analisis Model}

Analisis model dengan menggunakan metode Partial Least Square (PLS) yang meliputi (1) analisis model pengukuran (measurement model), dan (2) analisis model struktural (struktural model). Analisis model pengukuran berdasarkan outer model atau measurement model adalah penilaian terhadap validitas dan reliabilitas variabel penelitian. Analisis ini mengukur hubungan antara konstrak dengan indikatornya, artinya seberapa besar konstrak mampu mengandung keragaman data yang ada dalam setiap indikator dan seberapa besar keterkaitan hubungan antara konstrak dengan indikatorindikatornya. Dalam hal ini ada tiga kriteria untuk menilai outer model, yaitu convergent validity, discriminant validity, dan composite reliability. Model struktural berdasarkan inner model atau structural model,bertujuan untuk menguji hipotesis penelitian yang telah ditentukan sebelumnya, karena itu pengujian model struktural dilakukan untuk melihat hubungan antara konstrak.

1. Analisis Model Pengukuran (Measurement Model)

Analisis model pengukuran (measurement model) yang digunakan melalui analisis faktor konfirmatori dengan menggunakan pendekatan MTMM (MultiTrait-Multi Method)dengan menguji validitas convergent dan discriminant. (Campbell dan Fiske, 1959, dalam Latan, 2012 : 78). Validitas convergent berhubungan dengan prinsip bahwa indikator-indikator dari suatu konstrak seharusnya berkorelasi tinggi. Validitas discriminant berhubungan dengan prinsip bahwa indikator-indikator konstrak yang berbeda seharusnya tidak berkorelasi tinggi.

2. Uji Convergent Validity

Uji convergent validity indikator reflektif dapat dilihat dari nilai loading factor untuk tiap indikator konstrak. Angka yang digunakan untuk menilai convergent validity yaitu nilai loading factor harus lebih besar dari 0,7 untuk penelitian yang bersifat confirmatory dan nilai loading factoranatara 0,6 - 0,7 untuk penelitian yang bersifat exploratory masih dapat diterima serta nilai average variance extracted (AVE) harus lebih besar dari 0,5. Oleh karena penelitian ini masih dalam tahap pengembangan skala pengukuran, maka kriteria validitas convergent (convergent validity) menggunakan batas minimal nilai loading factor 0,5 - 0,6 masih dianggap cukup (Chin, 1998 dalam Latan, 2012 : 78). Atau harga $\mathrm{t}_{-}$statistik $>\mathrm{t}$-tabel. $_{\text {. Harga }} \mathrm{t}$ - 
tabel dengan derajat bebas $>120$ dengan harga $\alpha$

$=0,05$ adalah 1,96. Output nilai loading factor ini dapat dilihat dalam Tabel 1 berikut.

Tabel 1

HASIL UJI CONVERGENT VALIDITY OUTER LOADING(REFLEKTIF)

\begin{tabular}{|c|c|c|c|c|c|}
\hline Konstruk & $\begin{array}{c}\text { Original } \\
\text { Sample }(O)\end{array}$ & $\begin{array}{c}\text { Sample } \\
\text { Mean (M) }\end{array}$ & $\begin{array}{l}\text { Standard } \\
\text { Deviation } \\
\text { (STDEV) }\end{array}$ & $\begin{array}{l}\text { Standard } \\
\text { Error } \\
\text { (STERR) }\end{array}$ & $\begin{array}{l}\text { T-Statistics } \\
\text { (O/STERR) }\end{array}$ \\
\hline X.1 $\leftarrow$ Pengluaran Zakat $(\mathrm{X})$ & 0.8087 & 0.8013 & 0.0508 & 0.0508 & 15.9331 \\
\hline X.2 $\leftarrow$ Pengeluaran Zakat $(\mathrm{X})$ & 0.7218 & 0.155 & 0.0452 & 0.0452 & 15.9688 \\
\hline $\mathrm{X} .3 \leftarrow$ Pengeluaran Zakat $(\mathrm{X})$ & 0.7094 & 0.4170 & 0.1228 & 0.1228 & 3.3340 \\
\hline Y.1 $\rightarrow$ Kesejahteraan Mustahiq $(\mathrm{Y})$ & 0.8165 & 0.2780 & 0.2148 & 0.2148 & 2.1435 \\
\hline Y.2 $\rightarrow$ Kesejahteraan Mustahiq $(\mathrm{Y})$ & 0.7328 & 0.5277 & 0.2353 & 0.2353 & 2.5858 \\
\hline Y.3 $\rightarrow$ Kesejahteraan Mustahiq $(\mathrm{Y})$ & 0.9912 & 0.4555 & 0.2134 & 0.2134 & 2.3137 \\
\hline Y.4 $\rightarrow$ Kesejahteraan Mustahiq $(\mathrm{Y})$ & 0.8396 & 0.1912 & 0.1703 & 0.1703 & 1.9724 \\
\hline
\end{tabular}

Tabel di atas dapat memperlihatkan bahwa nilai-nilai yang ada pada kolom original sample untuk X.1, X.2, X.3 dan Y.1, Y.2, Y.3, Y.4 semuanya memiliki nilai diatas 0,7 . sehingga dapat dikatakan bahwa semua indikator valid dalam mengukur konstraknya.

\section{Uji Discriminant Validity}

Pemeriksaan selanjutnya adalah pemeriksaan nilai discriminant validity dari model pengukuran yang dinilai berdasarkan cross loading dan membandingkan antar konstrak. Discriminant validity yang baik akan mampu menjelaskan varian indikatornya lebih tinggi dibandingkan dengan varian dari indikator konstrak lainnya. Cross loading menggambarkan korelasi antara suatu indikator dengan konstraknya dan dengan konstrak lainnya. Jika korelasi konstrak dengan item pengukuran (setiap indikatornya) lebih tinggi dari korelasi dengan indikator dari konstrak lainnya, maka hal ini menunjukkan konstrak laten tersebut mampu memprediksi indikatornya dengan lebih baik dari pada konstrak lainnya (Yamin, 2009 : 42). Hasil dari cross loading dapat dilihat pada Tabel 2 berikut.

\section{Tabel 2}

CROSS LOADING UNTUK UJI DISCRIMINANT VALIDITY

\begin{tabular}{|ll|c|c|}
\hline \multicolumn{2}{|c|}{ Indikator } & $\begin{array}{c}\text { Pengeluaran } \\
\text { ZIS }\end{array}$ & $\begin{array}{c}\text { Kesejahteraan } \\
\text { Mustahiq }\end{array}$ \\
\hline Zakat & X.1 & 0.8087 & 0,4437 \\
\hline Infaq & X.2 & 0.7218 & 0,1304 \\
\hline Shadaqah & X.3 & 0.4094 & 0,0809 \\
\hline Fakir & Y.1 & 0.2369 & 0,5165 \\
\hline Miskin & Y.2 & 0.2486 & 0,7328 \\
\hline Subsistan & Y.3 & 0.1928 & 0,5912 \\
\hline Muzakki & Y.4 & 0.1125 & 0,2396 \\
\hline
\end{tabular}

Sebagai contoh, Tabel di atas memperlihatkan bahwa nilai loading factor untuk indikator X.1 adalah 0,8087. Indikator ini memiliki korelasi yang lebih tinggi dengan konstrak lainnya, yaitu Kesejahteraan Mustahiq $(0,4437)$. Semua nilai loading factor dalam konstrak Pengeluaran ZIS memiliki korelasi yang lebih tinggi dibanding dengan konstrak lainnya. Hal ini menunjukkan konstrak Pengeluaran ZIS mampu menjelaskan varian yang lebih tinggi dengan indikator X.1 - X.3 dibanding dengan indikator lainnya. Indikator Y.1 - Y.4 memiliki korelasi yang lebih tinggi dengan konstrak 
Kesejahteraan Mustahiq dibanding dengan nilai korelasi dengan konstrak lainnya.

4. Uji Reliabilitas (Reliability)

$$
\text { Evaluasi ketigaadalah melihat }
$$
composite reliability atau reliabilitas konstrak yang digambarkan oleh tabel composite reliability. Statistik yang digunakan adalah cronbach'salpha atau composite reliability. Pemeriksaan convergent validity dikatakan reliable jika nilai cronbach'salpha atau composite reliabilitydi atas 0,7 dengan kata lain menunjukkan konstrak memiliki reliabilitas atau keandalan yang tinggi sebagai alat ukur (Yamin, 2009 : 41). Namun demikian nilai cronbach's alpha yang dihasilkan oleh PLS sedikit under estimate sehingga lebih disarankan untuk menggunakan composite reliability(Latan, 2012 : 100). Hasil pengujian tersebut dapat dilihat pada Tabel 3 berikut :

\section{Tabel 3}

OVERVIEW CONSTRUCT INTERNAL CONSISTENCY

\begin{tabular}{|l|c|c|c|c|c|c|}
\hline & AVE & $\begin{array}{c}\text { Composite } \\
\text { Reliability }\end{array}$ & $\begin{array}{c}\text { R } \\
\text { Square }\end{array}$ & $\begin{array}{c}\text { Cronbachs } \\
\text { Alpha }\end{array}$ & $\begin{array}{c}\text { Commu- } \\
\text { nality }\end{array}$ & $\begin{array}{c}\text { Redu- } \\
\text { dancy }\end{array}$ \\
\hline $\begin{array}{l}\text { Kesejahteraan Mustahiq } \\
\text { (Y) }\end{array}$ & & & 0.1307 & & 0.2489 & 0.0048 \\
\hline Pengeluaran ZIS (X) & 0.5476 & 0.7428 & & 0.3904 & 0.4476 & \\
\hline
\end{tabular}

Berdasarkan hasil Tabel di atas, dapat diketahui bahwa nilai-nilai composite reliabiliy diatas 0,7 , sehingga dapat dikatakan konstrak memiliki reliabilitas yang baik sebagai alat ukur. Dapat dilihat pula bahwa nilai-nilai composite reliability lebih tinggi untuk semua konstak dibandingkan dengan nilai cronbach's alpha.

5. Analisis Model Struktural (Structural Model) Evaluasi model struktural bertujuan untuk melihat signifikansi setiap koefisien jalur yang menyatakan apakah ada signifikansi atau tidak adanya pengaruh antar variabel laten. Pengujian koefisien jalur pada inner model berarti juga meguji hipotesis yang telah ditetapkan yang tercermin pada jalur-jalur yang ada pada model.

Untuk menyimpulkan apakah hipotesis diterima atau ditolak digunakan kriteria : Jika $\mathrm{t}_{\text {-statistik }}>$ dari $^{\mathrm{t}}$-tabel $_{\text {tada }}$ pada derajat bebas dan tingkat kesalahan $(\alpha)$ yang
Berdasarkan hasil Tabel di atas, dapat diketahui bahwa nilai-nilai composite reliabiliy diatas 0,7 , sehingga dapat dikatakan konstrak memiliki reliabilitas yang baik sebagai alat ukur. Dapat dilihat pula bahwa nilai-nilai composite reliability lebih tinggi untuk semua konstak dibandingkan dengan nilai cronbach's alpha.

6. Analisis Model Struktural (Structural Model)

Evaluasi model struktural bertujuan untuk melihat signifikansi setiap koefisien jalur yang menyatakan apakah ada signifikansi atau tidak adanya pengaruh antar variabel laten. Pengujian koefisien jalur pada inner model berarti juga meguji hipotesis yang telah ditetapkan yang tercermin pada jalur-jalur yang ada pada model.

Untuk menyimpulkan apakah hipotesis diterima atau ditolak digunakan kriteria : Jika $\mathrm{t}_{\text {statistik }}>$ dari $\mathrm{t}_{\text {tabel }}$ pada derajat bebas dan tingkat kesalahan $(\alpha)$ yang 
ditetapkan. Dalam penelitian ini harga $\mathrm{t}_{\text {tabel }}$ dengan derajat bebas $>120$ dengan harga $\alpha=$ 0,05 adalah 1,96 . Jika $\mathrm{t}_{- \text {statistik }} \geq \mathrm{t}_{\text {-tabel }}(1,96)$ ;artinya terdapat pengaruh positif (signifikan),

Tabel 4

HASIL PENGUJIAN HIPOTESIS (PATH MODELING) maka Ha diterima dan Ho ditolak. Jika t-statistik $\leq \mathrm{t}_{\text {tabel }}(1,96)$; artinya tidak terdapat pengaruh positif (tidak signifikan), maka Ha ditolak dan Ho diterima.Hasil pengujian hipotesis jalur dapat dilihat pada Tabel 4 berikut :

\begin{tabular}{|c|l|c|c|c|c|c|c|}
\hline Hip & \multicolumn{1}{|c|}{ Jalur } & $\begin{array}{c}\text { Original } \\
\text { Sample } \\
\text { Estimate (O) }\end{array}$ & $\begin{array}{c}\text { Sample } \\
\text { Mean } \\
(\mathrm{M})\end{array}$ & $\begin{array}{c}\text { Standard } \\
\text { Deviation } \\
\text { (STDEV) }\end{array}$ & $\begin{array}{c}\text { Standard } \\
\text { Error } \\
\text { (STERR) }\end{array}$ & $\begin{array}{c}\text { T- } \text { Statistik }^{*} \\
\text { H }\end{array}$ & $\begin{array}{l}\text { Pengeluaran ZIS } \\
\rightarrow\end{array}$ \\
$\begin{array}{l}\text { Kesejahteraan } \\
\text { Mustahiq }\end{array}$ & 0.6981 & 0.6988 & 0.0334 & 0.0334 & 20.8751 & $\begin{array}{l}\text { Kigni- } \\
\text { fikan }\end{array}$ \\
\hline
\end{tabular}

Berdasarkan hasil perhitungan inner model pada Tabel di atas dapat disimpulkan sebagai berikut:

Dari hasil uji nilai t-statistics sebesar 20,8751, yang menunjukkan angka yang lebih besar dari t-tabel $=1,96 . \mathrm{t}_{\text {-statistik }}(20,8751)>\mathrm{t}$-tabel (1,96).Artinya Ho ditolak dan Ha diterima. Jadi dapat disimpulkan bahwa terdapat pengaruh yang signifikan dari variabel Pengeluaran ZIS terhadap Kesejahteraan Mustahiq, artinya bahwa semakin besar / baik pengeluaran ZIS, maka akan semakin besar / baik pula Kesejahteraan Mustahiq. Dengan kata lain jika kualitas Pengeluaran ZIS ditingkatkan secara baik, maka akan dapat memberikan dampak yang signifikan terhadap Kesejahteraan Mustahiq. Dengan demikian maka hipotesis terbukti dan dapat diterima.

\section{SIMPULAN}

Berdasarkan hasil analisis dan pembahasan yang telah dibuktikan, mengenai pengaruh pola pengeluaran zakat infaq dan shadaqah terhadap loyalitas serta peningkatan kesejahteraan muzakki dan mustahiq di Sulawesi Selatan, maka dapat di simpulkan dan di sarankan sebagai berikut :
Pengeluaran ZIS berpengaruh signifikan terhadap Kesejahteraan Mustahiq. Dengan demikian hipotesis dari penelitian ini terbukti dan diterima (Ho ditolak dan Ha diterima). Artinya bahwa semakin besar / baik Pengeluaran ZIS, maka akan semakin besar / baik pula Kesejahteraan Mustahiq. Dengan kata lain jika kualitas Pengeluaran ZIS ditingkatkan secara baik, maka akan dapat memberikan dampak yang signifikan terhadap Kesejahteraan Mustahiq.

\section{DAFTAR PUSTAKA}

\section{Jurnal / Artikel / Makalah :}

Anonim, Saudi Arabia : Department of Zakat and Income Tax, http://dzit.gov. sa/en/, diunduh tanggal 22 Agustus 2010 , Australia: The Islamic Associatian of Australia, http://www. irca.org.au/donation/index.htm, diunduh tanggal 22 Agustus 2010

Hidayat, Lc. \& H. Hikmat Kurnia, 2008, Panduan Pintar Zakat, "QultumMedia. Jakarta.". http $/ /$ www.qultummedia.com., diunduh tanggal 4 April 2011

Beik, Irfan Syauqi, 2008, Artikel Berjudul : Zakat Perusahaan dan Kemaslahatan Umat, 
Republika Online http $/ / \mathrm{www}$.republik a.co.id, diunduh tanggal 14 April 2008

Zadjuli, Suroso Imam, Prof. Dr. H., 2006, Kesejahteraan dan Keadilan dalam Perspektif Islam. Makalah disampaikan dalam seminar "Islam dan Isu-Isu Kontemporer" di Kantor Pusat IAIN Sunan Ampel Surabaya yang diselenggarakan oleh Fakultas UshuluddinIAIN Sunan Ampel Surabaya bekerjasama dengan Universitas Kebangsaan Malaysia pada tanggal 6 Juni 2006.

\section{Buku-Buku :}

Anonim, Departemen Agama R.I., 1998, AlQur'an dan Terjemahnya, Yayasan Penyelenggara Penterjemah/Pentafsir AlQur'an - Jakarta, PT. Intermasa, Jakarta.

Al-Utsaimin, Syaikh Muhammad Shalih, 2008, Ensiklopedi Zakat, Pustaka As-Sunnah, Jakarta.

Chapra, M. Umer, 2001, The Future of Economics : An Islamic Perspective, Shari'ah Economics and Banking Institute (SEBI), Jakarta.

Gamal, Merza, 2006, Model Dinamika Sosial Ekonomi Islam, Solusi Pembangunan Kesejahteraan Berkesinambungan dan Berkeadilan, Penerbit Unri Press, Pekanbaru.

Guritno, Bambang, 2007, Pengaruh Motivasi Pengeluaran Zakat Infaq Shadaqah terhadap Kepuasan Muzakki dan Kebahagiaan serta Loyalitas Muzakki di DKI Jakarta, Hasil Penelitian Disertasi.

Hafidhuddin, Didin, 2004, Zakat Infak Sedekah, Cetakan Keempat, Gema Insani, Jakarta

Sekaran, Uma, 1992, Research Methods For Business : A Skill Building Approach, $3^{\text {rd }}$ edition, New York, John Wiley \& Sons Inc.

Solimun, Nurjannah, Adji Ahmad Rinaldo, 2006, Pemodelan Persamaan Struktural : Pendekatan PLS dan SEM, Modul Pelatihan Aplikasi Software Smart PLS dan AMOS, Fakultas MIPA dan Program Pascasarjana, Universitas Brawijaya Malang.
Yamin, Sofyan dan Heri Kurniawan, 2009, Stuructural Equation Modeling, Belajar Lebih Mudah Teknik Analisis Data Kuesioner Dengan Lisrel - PLS, Salemba Infotek, Jakarta. 